\title{
РЕДАКЦИОННА СТАТИЯ
}

\section{Регламент на ЕС за оценка на зgраßните mехнологии - близо и gалече}

\author{
Георги Искров ${ }^{1,2}$, Румен Стефанов ${ }^{1,2}$
}

${ }^{1}$ Kamegра по Социална меgицина и общестВено зgраВе, Факултет по Обществено зgраВе, Меgицински униВерситет - Пловgив

${ }^{2}$ Институт nо реgkи болести, Пловguв

На 22 юни 2021 г. беше обяВено постигането на Важен пробив в преговорите межgу ЕВропейския парламент и CъBета на ЕС относно обхВата и cъgържанието на бъgeщия регламент на ЕС за оценка на зgравните технологии (03Т) [1]. Това споразумение бе приветстВано kато Важна cmbnka за постигане на множество цели, среg koumo nogoбрен gocmbn gо иновативни терапии за пациентите от EC и по-ефективно използВане на наличните зураВни ресурси В страните чкенки. КакBо точно се случи на тази gama и kakBo cлegBa ga очаkВаме?

На пърВо място, преgложението преgВижga съзgаване на коорgинационна група, Вk^ючВаща преgстаВители от Всяkа страна - чкенка на ЕС [1-3]. Групата ще работи В тясно сътруяничестВо с Всички заинтересовани страни на eßponeūcko равнище, cpeg koumo пациентски организации, меguцински сnециалисти, научни gружества и зуравна инgустрия. Неофициално се очакВа ЕВроnеūckama мрежа за 03Т (European Network for Health Technology Assessment, EUnetHTA) ga послужи kamo основа u ga преgостаВи работна рамkа за бъgeщата kоорgинационна груnа, npegвug очеВugнuте cхоgcmBa B cmpykmypama, uелume u обхВата на geūcmBue.

Основна заgача на бъgeщата kоорguнационна група ще бъgе изготВянето на съВместни gосиета за клинична оценка [1-3]. КАючовите моменти myk са няkолkо. ОЗТ на европейско ниво ще се ограничаßа само gо клинична оценка, m.е. анализ на зgравния проблем, анализ на безопасностmа, ефикасностma u mepaneßmичната ефективност на оценяВаната нова здраВна технология и сраВнителен анализ спрямо наличните алтернативи. Фармаkoukономичесkama оценка u оценката на бюожетното ВъзgейстВие остаВат изВън обхВата на съВместната ОЗТ.

Второ, страните членки ще бъgат заgължени gа използВат maka изготвените съßместни gосиета за клинична оценка и нещо повече - ga goknagBam kak me са Вкпючени и отразени в ОзТ решенията на национално ниво [1-3]. Tаkа gефинирани, pegъm и условията за ОЗТ на еВроneūcko paßнище ce npegBuжga ga Влязат $B$ сила gо 3 гоguни слеg прuема на регламента на EC [1-3]. Преgметьт на съВместните gосиета за клинична оценка ще се разширява прогресиВно, започВайки първоначално с онкологичните терапии [3]. Пъл- ното имплементиране на бъдещия регламент за 03Т се очакВа gа отнеме около 11 гоgини (ako самият регламент бъge официално приет).

Пътят kъм приемането на регламент на ЕС за ОЗТ има gълга преguстория u, kakmo изглежga, неясен завършек kъм gнешна gama. Oще по Време на geйсmßието на пърВия eBponeūcku npoekm за 03T - EUnetHTA Project (2006-2008) се заговори за съзgаване на общоеВропейска нормативна рамkа за ОЗТ и изготВяне на съВместни ОЗТ gokıаgu om страните-членки на ЕС. ТоВа, разбира се, са съВсем рационални иgеu. Оm еgна страна, gържаВите членки и техните 0ЗТ институции gублират сВоите цели и функции. Ekcnepmният onum u ресурси за 03Т са ограничени и разпрьснати [4-5]. Om gруга страна обаче, процесьт за приемане на този регламент буксува Вече gьлго Време.

Причините за това са не еgна или gве. Политиката на EC постаВя принципа на субсuguарност на централно мясmo В сферата на зgраßеопазВането и зgраВната nолumuka. Това означаВа, че страните членки имат своuте специфични праВомощия и компетенции В тази област, които трябва ga бъgam зачитани и Вземани поg Внимание [6]. ОЗТ е gобър наглеgен пример, kьgemо националните интереси на gьржаВите-членки на ЕС вземат Вpbx наg общоеВроnейсkume. Tова е maka, защото $B$ наши gни процесът на 03Т е тясно сВързан с ценообразуВането и реuмбурсирането на зgравни технологии на национално ниВо. И gokamo ОЗТ по презумпция е строго научен nоgхоg, базиран на gоказателства, ценообразуВането и реимбурсирането от gруга страна са Важни праkтичесkи инструменти за Воgене на зgравна поnumuka.

Примерът с конфugенциалните omcmbnku u yckopeния gостьп gо иновативни зgравни технологии, които еgни gържаВи са В състояние ga gоговорят за своите здраВни системи, а gруги gьржави не, е повече от достатьчен. Всички страни-членки на ЕС формално провежgат 03Т. Меmоgологията за този процес е gо голяма степен уеgнакВена. Om gълги гоgини специалистите по ОЗТ от различни еВроneūcku gържаßи си сътрудничат и обменят оnum и gобри nраkmuku. Защо тогаВа ОЗТ Воgu gо различни резултати $\boldsymbol{B}$ различните страни? Защото В крайна сметка това е колkото научен, mолкова и строго специфичен за всяка страна процес. Страните-членки на ЕС имат различни по mun зgравни системи, различни зgраВни потребности, различни здраВни ресурси. Процесьт на ОЗТ и решенията В крайна сметkа трябВа ga се съобразяВат с тази gейстВителност [7].

И Все nak, изготВянето на съВместни gосиета за клинична оценка има повече преguмства omkonkomo неgостаmъци kъм настоящия момент. И gосега страните-членки 
на EC ползВаха gо голяма степен еgин и същ набор клинични gанни от научноизслеgователсkаma програма на gаgена зураВна технология. Опреgелено има резон еgни и същи резултатu ga се оценяВаm Begнъж и еgнократно за целия EC. Проблем обаче е сравнителният анализ. АлтернатиВите за сраВнение не Винаги са еgни и същи. Межgунароgните meраnевтични pъkoßogcmßa може ga са еgнаkВи, но не Винаги изброените 8 тях nogxogu са намични и gостьпни ВъB всяkа страна. ТоВа е Важен фактор, който потенциално променя nepcnekmußama за оценка u хипотетично може сериозно ga разВоgни работата по изготВянето на съВместни gосиета за клинична оценка.

Дали В kрайна сметка ще се стигне gо приемане и прилагане на регламент на ЕС за ОЗТ преgсmou ga ce Bugu. Ha moзи eman moßа изглежga kолkomo опраВgана, mолkоВа u puckована заgача. Проgь^жаßащuте с гоgини обсъжgания no mози Bъnрос опреgелено загатВат, че няма постuгнат консенсус межgy страните-членкu на ЕС. Настоящата панgемия обаче и произтичащите от нея зgраВни, социални и ukономичесkи послеgствия може ga променят цялостната конфигурация по тази тема.

\section{Бибмиография}

1. European Parliament. Deal on boosting member states' cooperation in assessing health technologies, press release, 22 June 2021 https://www.europarl.europa.eu/news/en/pressroom/20210617IPR06472/deal-on-boosting-member-statescooperation-in-assessing-health-technologies

2. European Parliament. Legislative train. 4 a deeper and fairer internal market with a strengthened industrial base / products / up to $€ 183$ bn. Health technology assessment (HTA). https://www.europarl.europa.eu/legislative-train/theme-deeper-andfairer-internal-market-with-a-strengthened-industrial-base-products/filehealth-technology-assessment

3. Council of the European Union. Health technology assessment post 2020. Partial mandate for negotiations with the European Parliament, 24 March 2021 https://www.consilium.europa.eu/media/48963/st07310-en21.pdf

4. Vella Bonanno P, Bucsics A, Simoens S, et al. Proposal for a regulation on health technology assessment in Europe - opinions of policy makers, payers and academics from the field of HTA. Expert Rev Pharmacoecon Outcomes Res. 2019 Jun;19(3):251-261.

5. Kaló Z, Gheorghe A, Huic M, et al. HTA Implementation Roadmap in Central and Eastern European Countries. Health Econ. 2016 Feb;25 Suppl 1(Suppl Suppl 1):179-92.

6. Stühlinger V. Health Technology Assessment (HTA) and Access Policies. Eur J Health Law. 2020 May 7;27(3):274-289.

7. Nicod E, Maynou L, Visintin E, et al. Why do health technology assessment drug reimbursement recommendations differ between countries? A parallel convergent mixed methods study. Health Econ Policy Law. 2020 Jul;15(3):386-402. 